\title{
Indication of Moral Erosion in Children's Fiction
}

\author{
Wahyu Wiji Astuti ${ }^{1}$, M. Anggie J. Daulay ${ }^{2}$, M. Oky F. Gafary ${ }^{3}$ \\ 1,2,3 Universitas Negeri Medan, Indonesia \\ Email:wahyu_wiii@yahoo.com
}

\begin{abstract}
Children literature has an important role in children development. Based on the research, there is a different between intellectual and character from child who is a bookworm and who is not. Reading fiction is a favorite of children. Children tend to identify themselves into a character in a fiction, therefore proper rules needs to be put into consideration. This paper aims at underlining problems in children fiction which are potentially eroding children's morality. Analysis is done by studying the value and structure in children's literature. It needs to be reconstructed, so reading habit of children will not drop them down to moral erosion.
\end{abstract}

Keywords: children literature; fiction; moral; didactic

\section{Introduction}

Children's life are a world full of imagination. Children tend not to be able to control themselves and emotions in an established way. This study was carried out on the basis of concerns about criminal cases committed by underage children which recently occurred in Indonesia. These cases were very diverse and spread in regions in Indonesia. It could be seen from the news in various media. Criminal acts committed by adolescents in these cases were not based on accident, but include conscious and planned acts committed in a sadistic manner. Such things that only psychopaths and people with mental disorders could think about. The bitter fact that children today easily commit sadistic crimes because of desires that are not conveyed.

Modernization nowadays which has permeated the various spheres of life has affected the young generation. Ease of access to the content of pornography makes children easily reach things that should not be known in their age. This problem can causes moral degradation that can be seen from the language, appearance, behavior and the social milieu of the children today. For this reason children need to be educated from an early age and given understanding through educating reading.

Development of children's mental health is needed to be done since early. One of the efforts is through literature. Children's literary works contain moral values which educate children through interesting stories (fiction). Through stories, children are not only gain the stories, but analyze the logical relationships between events, so that their intellectuals will be activated (Nurgiyantoro, 2013: 38). Many of children's fiction are adapted from fairy tales and folklore that retold and transformed into various forms. Folklore is known to contain many moral values that teach children about goodness. Yet sometimes we forget that the possibility to absorb negative things in the story can be happened.

This possibility is caused by many factors, including the fictional stories taken from folklore often present events, characters and bad attitudes as a comparison for good characters, but do not achieve completeness. Children who are still not perfect in comparing between good and bad ultimately identify themselves as the characters in the story closest to them. This is influenced by psychological conditions that are still unstable, sensitive, easily influenced, and tend to easily do deviations from values or norms. In certain cases, the genuine purpose of children's fiction that is to build children's morals actually erode their morals. 


\section{Britain International of Linguistics, Arts and Education (BIoLAE) Journal \\ ISSN: 2685-4813 (Online), 2685-4805 (Print) \\ Vol. 1, No. 2, November 2019, Page: 42 - 50}

For this reason, it is necessary to look at how far the children's fiction teaches moral values, and how the telling of children's fiction causes indications of moral erosion. So the data in this research are children's fiction taken from North Sumatra folklore, entitled Asal Usul Danau Toba (The Origin of Lake Toba). The study is carried out by explaining the structure to see the values and indications of moral erosion.

\section{Review of Literature}

\subsection{Theory of Structuralism}

Structuralism is a theory that analyses literary works as an autonomous work. Faruk (2012: 173) explains that structuralism is a concept that everything in this world has a structure, working structurally. The emphasis of structuralism studies on literary works is the autonomy of interconnected structure (Kurniawan, 2009: 69). Literary works are complex objects, including children's fiction. Every object or event is a structure that consists of various elements that every element has a relationship (Siswantoro, 2014: 12). Thus the existence of fiction as a form of literary work as a complex object is different from other types of literary works.

The elements of fiction are including the facts, theme and the literacy device (Stanton, 1964: 11). Story facts or factual structures are elements that can be directly identified in fiction. The fact of the story consists of elements of character, plot and setting. These elements shape the reality of life, namely human beings as characters, spaces and places that become the setting and movement from space to space as the plot.

Characters are individuals who are present as actors in a story. Characters in fictional stories are usually more than one person and the amount varies, but the presence of the main character in the story is directly related to the events in the story (Stanton, 1964: 17). While the additional characters are only as a complement to the story as well as the main character.

Stanton (1964: 15) states that the plot is a series of events that are interconnected each other to form a story. Stages of events that establish a story can be formed in a series of various kinds of events (Aminuddin, 2013: 83). In a fiction, the plot consists of the beginning, middle and end.

The setting is the platform where the events occur. The setting usually involves the place, time and social setting. As one of the building elements of fiction, the setting always has a relationship with other elements in constructing the totality of meaning and unity (Aminuddin, 2013: 69).

The theme is the main thought of the writer which becomes the soul and the basis of the story. The theme in the story is related to the meaning of life experience. Interpretation of the theme of the story according to Stanton is paying attention to several things, specifically to interpret the story must be focused on the prominent description; to interpret the theme should not conflict with each description of the story; it should not depend on the information that actually exists; and must be based directly on the story (Kurniawan, 2009: 77).

Literary device is a method used by the author in compiling and selecting parts of the story, so that meaningful literary works will be created (Kurniawan, 2009: 77). The elements of literary device included the title, point of view, style and tone, symbolism and irony. The point of view is how or in what way the author tells a story; from the point of view of who the story is told. 


\subsection{Moral Value}

Moral values are good values in the attitude and action based on the norms and regulations that bind a group of societies in the community. Children's fiction must contain moral values that educate children. Rohmah (2010: 42-43) explains from the results of his study that the outline of children stories from domestic and foreign countries have the same universal values in the form of: the moral domain content of personality, the moral domain content of social values and the moral domain of religious values.

The moral domain content of personality, personality including 1) acts discreetly; 2) honesty / dishonesty; 3) courage 4) criticism and creativity. 5) Modesty; and 6) accountability. While the content of the moral domain social values consists of seven taxonomies, namely: 1) respect for others; 2) cooperation; 3) the solidarity among friends; 4) the value of recognizing the rights of others; 5) taxonomy of deliberation value; 6) discipline; and 7) affection.

Children's personality will be developed by reading literary works. Locke explained that a child will experience personality development through a process of association and imitation. The association process is related to the child's ability to identify events that are considered to be the same, while imitation is a learning process carried out by imitating (Kurniawan, 2009: 42). Thus it is necessary to present both the reading material and a good environment for children so that the process of establishing the child's personality are effective.

\section{Research Method}

The method that will be used in this study is a qualitative method. Qualitative research is defined as a research that does not perform calculations (Moleong, 1989: 2). Bodgan and Taylor (through Moleong, 1989: 3) define qualitative methodology as a research procedure that produces descriptive data in the form of written or oral words. The research steps are: 1) data collection; 2) data selection; 3) recording data; 4) analyzing data in based on the theory; 5) writing the result of the data. To answer the problem of indications of moral erosion in children's fiction is done first by analyzing its elements using the theory of structuralism, then the contents of the story will be identified to enable the child's misunderstanding in the reflection while seeing the value in the story.

\section{Discussion}

The results of the analysis on children's fiction entitled "Asal Usul Danau Toba (The Origin of Lake Toba)" is done by describing the structure as well as its relationship with the elements in it.

\subsection{Facts of the Story}

The character in the children's fiction entitled Asal Usul Danau Toba consists of three people, they are a young man named Toba, Toba's wife - an incarnation of fish, and Samosir who is the son of Toba and his wife. The portrayal of the characters in child fiction is done directly in the narration, because children are usually not able to capture the situational conditions in the character's portrayal through dialogue. This can be seen from the following quotation:

Pemuda ini hidup sebatang kara dan cukup miskin. Setiap hari dia bertani untuk memenubi kebutuhanya. Dan ketika dia memiliki waktu senggang, dia pergi memancing untuk mencari lauk. Si Toba adalah seorang pemuda yang rajin, namun dia belum juga memiliki isteri karena kehidupanya yang serba binaan oleh tetangganya. Namun si Toba tetap bersabar. 
This young man lives alone and is quite poor. Every day he farms to fulfill his needs. And when he has free time, he goes fishing to make side dishes. Toba is a diligent young man, but he does not yet have a wife because of the lack of his life. So that sometimes he is often being insulted by his neighbors. But the Toba remained patient.

Samosir sangat dimanja oleh ibunya, sebingga hal tersebut menjadikan Samosir anak yang manja dan cukup nakal. Berkali-kali si Toba dibuat marah oleh ulah Samosir, namun setiap kali dia ingat janjinya pada isterinya, dia berusaha menaban emosinya. Babkan Samosir menjadi anak yang sangat malas dan sukanya hanya bermain-main saja. Setiap kali dia disurub ibunya untuke mengantar nasi untuk ayahnya di sawah, dia selalu menolak. Hingga ibunya sendiri yang harus mengantarnya.

Samosir was very spoiled by his mother, so that made Samosir a spoilt and naughty child. Toba was repeatedly angered by Samosir's actions, but every time he remembered his promise to his wife, he tried to hold back his emotions. Even Samosir became a child who was very lazy and liked to just play around. Every time he was told by his mother to deliver rice to his father in the fields, he always refused. Finally his mother had to drive it by herself.

Based on the story, the character of Toba is a young man who is poor and living alone. He was very patient in living his life even though he was often insulted by others. His life transformed since he discovered the fish which was the incarnation of a Goddess and later became his wife. However, his life changes when he is angry with his child and accidentally breaks his promise, saying that his child is a descendant of fish.

The character of the wife is the incarnation of a goddess who is cursed into a fish. After being provoked by Toba, he turns into a human and lives happily with Toba and their son, Samosir. This character is told as a beautiful and loving woman.

Samosir is the son of Toba and his wife. Because of her mother's excessive love for him, he grew up to be a spoiled and naughty child. Mischief committed by Samosir turn on the anger of his father as resulting in disaster.

The naming of characters in a child's fiction is related to the setting in the story. The setting in the fiction is located in North Sumatra, precisely on Lake Toba. This setting is the name of the character in the story. Furthermore, the setting of the places mentioned are in the river, rice fields, forest, and in Toba's house (room, kitchen). The background depiction in this story is not pictured in details and uses description, but only mentioning the location where the event occurred directly. The background depiction can be seen from the following quotation:

Dengan hati senang si Toba pulang ke rumahnya, dia membayangkan betapa lezatnya ikan itu nanti ketika dipanggang. Setelah sampai rumah, si Toba menaruh ikan itu di dapur. Namun karena kayu bakarnya habis, dia pergi mencari kayu bakar dulu di butan di dekat rumabnya.

Toba returned to his home with a delighted heart, imagined how delicious the fish would be when it is roasted. After arriving home, the Toba put the fish in the kitchen. Since the wood was run out, he went to look for firewood first in the forest near his house. 
The time setting in the story is also not specifically explained. In a folklore, the setting of time usually only uses the information "in ancient times, one day, in that era," and so on. Since folklore fiction is unidentified when it was made and it is also anonymous. The setting of time in this story is as follows.

\section{Dabulu kala, di daerah yang sekarang disebut Sumatera Utara biduplah seorang pemuda} bernama Toba.

Long time ago, in the place that now called as North Sumatra there lived a young man named Toba.

Hingga pada suatu hari, si Toba berniat memancing di sungai untuk mencari lauk. Diapun pergi membawa kail menuju sungai.

One day, Toba intends to go fishing in the river to look for side dishes. He went there with a hook.

Namun pada suatu hari, samosir di surub ibunya mengantar nasi untuk ayahnya ke sawah. Karena suatu alasan membuat ibunya tidak bisa mengantarnya.

However one day, Samosir was told by his mother to deliver the food for his father in the rice fields. For some reason his mother could not do it by herself.

The origin of the story Toba (The Origin of Lake Toba, in accordance with the title and a background in the story, it has a social background Batak Toba people who live in the Samosir area, North Sumatra. The Toba Batak community adheres to a patriarchal culture which is man who are determinants of lineage. This is implicit in the story that Toba as a husband and father is highly respected by his wife.

The plot in the story of Asal Usul Danau Toba uses a simple storyline. Events are told chronologically from beginning to the end. The stages of the plot include exposition, conflict, climax and denouement. The exposition stage is during the initial introduction to the life conditions and background of the Toba's character, the event when he is fishing, when the fish turned into a beautiful woman, and the events of his life with his small family.

The conflict stage in the story is when Samosir was told by his mother to deliver food to his father (Toba), instead of doing it, he played around and ate the food. Conflict also occurred when his father scolded Toba and called him a child of fish. The conflict also culminated into the climax stage when his wife heard Toba's words that Samosir was a child of fish. Then his wife was angry because Toba had broken his promise.

The climax of the story is in the event of his wife's anger, she told her son to climb into a tree on a hilltop, and then she jumped into the river and turned into fish. More details can be seen in the quotation below:

Mendengar penjelasan anaknya, ibunya merasa kecewa karena ternyata janji yang dibuatnya telah dilanggar. Dia segera menyuruh anaknya untuk pergi ke bukit dan memanjat pohon tertinggi di puncak bukit.

Samosir pun berlari hingga tiba di atas bukit dan mendaki pohon tertinggi seperti perintah ibunya. Setelah itu, wanita itu pergi ke tepi sungai dan terjun ke dalam sungai. Seketika itu, 
dia kembali berubah menjadi ikan yang sangat besar. Secara tiba-tiba, hujan lebat turun disertai angin dan Guntur. Air sungai juga meluap, banjir dimana-mana. Banyak orang yang tidak bisa menyelamatkan diri, termasuk si Toba. Kawasan itu berubah menjadi genangan air yang cukup luas dan semua tenggelam di dalamnya. Kecuali sebuah bukit yang kini hanya terlihat sedikit bagian puncaknya.

Hear her son's explanation, the mother was disappointed that the promises her husband made have been violated. She immediately told her son to go to the hill and climb the highest tree on the hilltop.

Samosir ran to the top of the hill and climbed the tallest tree as his mother ordered. After that, the woman went to the river's edge and jumped into the river. Instantly, she turned into a very large fish. Suddenly, heavy rain fell with the wind and thunder. River water also overflowed, flooding everywhere. Many people cannot save themselves, including the Toba. The area was turned into a large puddle of water and all sank in it. Except for a hill that now only able to see able little part of the peak.

After reaching the climax stage, the plot turn down to the denouement towards completion. The finishing point is illustrated by the event of the sinking of the entire area and becoming a lake. This stage can be seen in the following quote:

\section{Akbirnya, daerah itu menjadi sebuah danau yang cukup luas, yang kini kita kenal dengan nama Danau Toba yang berada di Sumatera Utara. Dan bukit kecil yang didaki oleh Samosir, kini menjadi sebuah pulau yang terletak di tengah-tengah danau, dan dikenal oleh penduduk sekitar dengan nama Pulau Samosir.}

Finally, the area became a fairly large lake, which we now know by the name of Lake Toba in North Sumatra. And the small hill that is climbed by Samosir, is now an island located in the middle of the lake, and is known by people around as Samosir Island.

\subsection{Theme}

The theme is the main idea in a story. The main idea in this children's fiction entitled Asal Usul Danau Toba (The Origin of Lake Toba) is "the obedience to keep promises", a main theme that teaches obedience and the importance of keeping promises to children. As a result of not being obedient to parents, it causes an anger. In addition, due to excessive anger, he forgets his promises, that is also causing a great disaster and regret.

The theme element is undeniably related to the factual element in fiction. The relationships are in the plot, in determining the theme begins with the initial exposure of Toba characters, Toba's meeting with the fish incarnation, until they get married and conflict arises until a major disaster occurs. In this explanation it can be seen a clear relationship between the plot, setting, characters and themes.

\subsection{Literary Device}

Literary devices include things that support the telling of a fiction, one of them is the title. The title "Asal Usul Danau Toba (The Origin of Lake Toba)" is directly related to the central of the story, which is the background of Lake Toba in North Sumatra. Thus there are no metaphors or meanings hidden from the title of the fiction. This is in accordance with the 
characteristics of children's stories that use straightforward language and easily understood by children.

The point of view in the child's fiction uses the third person's perspective. Authors are people beyond the story. In this point of view the name of the character, frequently and repeatedly referred to and as a variant pronoun is used (Nurgiyantoro, 2000: 256). The author tells the story clearly from one event to another. In other words, the author as a narrator is omniscient. The storytelling style in this fiction also mostly uses narrative, simply inserting little dialogue. It is a characteristic of folklore that the author is a storyteller.

In this children fiction uses simple and straightforward language. The diction used is also very easily understood by children. Besides this story does not use the game of metaphors and other figurative languages. As language in child fiction is not a complex as adult fiction. The symbolism used in children's fiction is in the names of the characters, Toba and Samosir who symbolize the names and characteristics of an area in North Sumatra.

\subsection{Identification of Moral Value and Indication of Moral Erosion in the Fiction}

Based on moral analysis conducted on this children's fiction "Asal Usul Danau Toba (The origin of Lake Toba)", it is known that many moral teachings are beneficial for children's mental development. The values contained in the fiction include acting cautiously so will not make bad effects and regret, obedience, discipline that includes loyalty and obedience to parents, obedience to regulations and good advice. Patience, is an attitude of being patient and perseverance in dealing with problems, not easily discouraged, and able to hold emotions. Keep promises, is a consistent attitude towards what is said and what is done, and respect for others.

Storytelling is done by including conflicts and depictions of bad things that occur in the story as a comparison. It is natural indeed, that the contents of children's stories do not have to be merely the good one, children can also accept "bad" stories such as lazy children, lying children, lazy cats or animals who like to eat their fellows (Nurgiyantoro, 2013: 7 ). Nevertheless, this must be accompanied by wise telling.

Children tend to identify themselves to the characters who are the closest and most similar to them. Based on the analysis of the fiction of Asal Usul Danau Toba (The Origin of Lake Toba), there are three characters contained in the story, namely Toba, Toba's Wife and Samosir. From the three characters, the greatest tendency of children to identify themselves is with the character Samosir. Because of Samosir is the only child character in the story. Children's experiences are still limited, so they cannot understand stories that involve complex life experiences (Nurgiyantoro, 2013: 9).

Samosir is a spoiled boy. Her mother loved Samosir and pampered her so much that she grew up to be a mischievous child. In this case, Samosir made no mistake because his attitude grew naturally due to his often spoiled motherly behavior. Samosir's mischievous attitude is simply because he doesn't know what is right and what is not right to do, because the mother has never scolded her child when it was wrong. As a result, the child has lack awareness of his bad behavior.

Samosir's mistake in the story was when he ate the food that was supposed to be his father's. Therefore the father rebuked him by saying he was "a child of fish". In this case, children take lessons about honesty, obedience and respect for the rights of others. Because of his mistakes, he was scolded by his father. But then his mother defended Samosir by telling him to climb the tree on the highest hill to save him from disaster. 
The incident illustrates the love of a mother to her child more than anything in the world. So even if he did something wrong, the mother would defend. Whereas the point of the children towards bad behavior with punishment are set off together, and the greater the mistake the more severer the punishment (Nurgiyantoro, 2013: 54). However, the story of the mother who defended Samosir made the figure of the mother as an absolute shelter for children, so that the child will not be afraid if making a mistake because it will definitely be protected by parents and not get a penalty. This is an indication of moral erosion in children.

It can be seen from the reflection of life today, for example in the case of a teacher who was jailed for punishing a naughty student. In addition, there are also cases of parents fighting each other for defending their children and so on. In addition to not causing a deterrent effect for children who make mistakes, children become not independent (spoiled) and reliant on their parents, also make them arrogant and feel more powerful because of the existence of their parents. Since he does not bear the consequences of his actions, but rather someone else is to blame and suffer the consequences.

Additionally, the events in the story imply the attitude of children who get what they want. Children will identified values that he can take whatever he wants in any way. This can cause a child's mental growth to be selfish.

Another indication that can be seen is the attitude of children who become disrespectful to parents. Parents are considered as an emotional person just because of food then he rebuked him in such a way. Thus parents as sentimental figures for directly condemning the place became a natural disaster because of her anger. This event also shows the fragility of parents that is not good to be a role model.

This can be occurred because of a telling that does not reach the completeness of the message that should be delivered. A child still has limitations in the analysis and logic of thinking so that his understanding only reaches the chronology of the story's events. Children have psychiatric conditions that are still unstable, sensitive, easily influenced, and tend to easily do things that deviate from values or norms so that it appears the child's possibility to take the negative side of events.

For that reason, in writing children's fiction, it is necessary to explain the balance of characters and the good way of telling. An explanation of what should be imitated and not also important in fictional narratives. Besides, the balance of the consequences arising from an action or event also needs to be considered so that children can take the message in fiction properly. The role of adults is also important in terms of meaning and understanding of children. Thus the purpose of children's literature will be achieved accurately and on target.

\section{Conclusion}

Children's fiction entitled "Asal Usul Danau Toba (The Origin of Lake Toba)", is known to have many moral teachings which beneficial for children's mental development. On the contrary, in its presentation also indicates the erosion of moral values. A well-defined explanation of what is good and bad is needed, a balance of the consequences of an action or event, as well as the role of an adult in understanding and giving understanding to children are the things that should be done to prevent the moral erosion to be happened. 


\section{References}

Aminuddin. (2013). Pengantar Apresiasi Karya Sastra. Bandung: Sinar Baru Algensindo.

Faruk. (2012). Metode Penelitian Sastra: Sebuah Penjelajahan Awal. Yogyakarta: Pustaka Pelajar.

Kurniawan, Heru. (2009). Sastra Anak: dalam kajian Strukturalisme, Sosiologi, Semiotika bingga Penulisan Kreatif. Yogyakarta: Graha Ilmu.

Moleong, L.J. (1989). Metodologi Penelitian Kualitatif. Bandung: Remaja Rosda Karya.

Nurgiyantoro, Burhan. (1998). Teori Pengkajian Fiksi. Cet. II. Yogyakarta: Gadjah Mada University Press.

Nurgiyantoro, Burhan. (2000). Teori Pengkajian Fiksi. Yogyakarta: Gadjah Mada University Press.

Nurgiyantoro, Burhan. (2013). Sastra Anak: Pengantar Pemahaman Dunia Anak. Yogyakarta: Gadjah Mada University Press.

Rohmah, Galuh Nur. (2010). Pengaruh Nilai Cerita Anak Dan Kesusasteraan Dalam Menciptakan Pendidikan Humanis Bagi Anak Indonesia.

Sarumpaet, Riris K.Toha. (2010). Pedoman Penelitian Sastra Anak. Jakarta: Pusat Bahasa Kementerian Pendidikan Indonesia.

Siswantoro. (2014). Metode Penelitian Sastra. Yogyakarta: Pustaka Pelajar.

Stanton, Robert. (1964). An Introduction to Fiction. New York: Holt, Rinehart and Winston Inc. 